\title{
POHJOISMAINEN AIKUISKASVATUSYHTEISTYÖ ON MUUTOKSEN KOURISSA
}

\section{Kiinteistä toiminnoista siirrytään ohjelmiin ja projekteihin}

\author{
Vuodesta 1968 toiminut pohjoismaiden yhteinen kansanopisto, Nordens \\ Folkliga Akademi Göteborgissa lopetetaan. Lakkauttamisuhasta on \\ puhuttu jo vuosia. Nyt päätös on selvä: koko maailman mittakaavassakin \\ ainutlaatuisen kansanakatemian ovet sulkeutuvat ensi kesänä. Kun \\ akatemia vihittiin käyttöönsä 35 vuotta sitten idyllisessä Kungälvissa \\ Göteborgista pohjoiseen, arvovieras vihkiäisissä oli Olof Palme.
}

Pohjoismaiden Ministerineuvoston alaisen aikuiskasvatuksen johtoryhmän FOVU:n suomalainen jäsen, opetusneuvos Reijo Aholainen sanoo Pohjoismaiden yhteistyön yleisemmäksikin ongelmaksi instituutioiden suuren määrän, minkä johdosta kiinteät kulut syövät yhteistyöbudjetista muhkean osan.

Pohjoismaiseen sivistys ja tutkimus -yhteistyöhön käytetään tänä vuonna 27 miljoonaa euroa, josta erilaisten instituutioiden kiinteitä kuluja on noin puolet. Aikuiskasvatuksen ja vapaan sivistystyön budjetti on vuorostaan vajaat 2,3 miljoonaa, mistä Nordens Folkliga Akademiin osuus 0,8 miljoonaa euroa ja siitä on kiinteistökuluja puolet.

\section{VIISI UUTTA OHJELMAA, VIISI VASTUUMAATA}

Yhteistyö suunnitellaan rakennettavaksi viiden ohjelman varaan siten, että kukin pohjoismaa saa vastuulleen yhden ohjelman.

Tanska saa juuri aikuiskasvatuksen ohjelman VOKSENin ja sitä alkaa hallinnoida meidän CIMOa vastaava CIRIUS-keskus Kööpenhaminassa. Ei vain suomenkielisten suomalaisten, vaan myös Suomen ruotsalaisten aito pelko on, että Voksenin muuttuessa tanskankieliseksi Suomi syrjäytyy pohjoismaisesta aikuiskasvatusyhteistyöstä. Pitkäaikaiset, turhauttavat kokemukset siitä, että tanskalaiset puhuvat pohjoismaisissa 
yhteyksissä vain tanskaa ja edellyttävät sillä selviämistä myös muilta, ei suomalaisia aikuiskasvattajia rohkaise.

Voksenin rinnalle rakennetaan Nordplus-ohjelma, joka muodostuu neljästä liikkuvuus- ja tukiohjelmasta. Niistä Suomelle tulee euromäärältään suurin ohjelma, uusi Nordplus. Se on korkeakouluohjelma, jonka tehtävänä on luoda ja vahvistaa yliopistojen välisiä verkostoja sekä edistää opiskelijoiden ja yliopisto-opettajien liikkuvuutta. Suyomessa ohjelmaa hallinnoi CIMO.

Ruotsille tulee nuoriso-ohjelma Nordplus junior ja Norjalle lähialueyhteistyötä (mm. Venäjäja Baltia-yhteistyötä) edistävä Nordplus nabo. Ohjelmasta vastaa Norsk Forskningsråd. Islannille menee kieliohjelma Nordplus sprog ja hallinnoija on Reykjavikin yliopisto.

Toiminnot muutetaan siis kokonaan ohjelmiksi ja projekteiksi. Myös aikuiskasvatuksen johtoryhmä FOVU muuttuu, ainakin nimensä puolesta. Uudet projektiohjelmat (Voksen, Nordplus, Nordplus junior, Nordplus nabo ja Nordplus sprok) tulevat mm. NFA:n koulutukseen osallistumisstipendien, blokkituen ja yksittäisten projektien tilalle.

\section{MUUTOKSEN RAJUUS NOSTATTI KRITIIKKIÄ}

Kaavailtu ja joulukuussa opetusministereiden kokouksessa päätettävä muutos nostattaa rajuutensa vuoksi kritiikkiä.

Opetusministeriön pohjoismaisesta yhteistyöstä vastaavan opetusneuvos Reijo Aholaisen kokoon kutsumassa järjestöjen informaatio- ja keskustelutilaisuudessa torstaina 6. marraskuuta kiinnitettiin vakavaa huomiota siihen, että ohjelmien kansallinen koordinointi on uudistustyössä jätetty avoimeksi. Kuten Reijo Aholainenkin huomautti, kansallisesti on vaikeaa ellei mahdoton löytää sellaista kokoavaa tahoa, joka edustaisi tasapuolisesti koko "kenttää", mitä sillä kukin tarkoittaakin. Kansan Sivistystyön Liiton pääsihteeri Jukka Tainio ehdotti sen vuoksi ratkaisumallin etsimistä kansallisesti erityisohjelmille luotavista kotimaisista verkostoista ja tiimeistä, joilla turvattaisiin "eri tahojen" läsnäolo.

Blokkituen avulla ovat aatteellisesti toisiaan lähellä olevat aikuiskasvatusjärjestöt voineet ylläpitää pohjoismaista yhteistyötä. Pahimmillaan blokkituen poistuminen merkitsee yhteistyön näivettymistä, ainakin pahaa notkahdusta:
- Blokkirahoituksen poistuminen on raju muutos, kommentoi Svenska studieförbundetin opintojohtaja Björn Wallen. Hän edustaa keskiryhmien ja sitoutumattomien opintokeskusten yhteistä FNV:tä (Förbundet Nordiska Vuxenupplysning). Järjestö onkin ehdottanut vuodenmittaista ylimenokautta, sillä nyt suunniteltu muutos pakottaa järjestön lopettamaan yhteistyöstä vastaavan yhden hengen toimistonsa Oslossa.

Kaikkien neljän Nordplus -ohjelman (Nordplus junior/ Ruotsi, Nordplus/Suomi, Nordplus sprog/ Islanti ja Nordplus nabo/ Tanska) koordinoinnin mahdollinen päätyminen ruotsalaiselle CFL:1le (Center for Flexibel Lärande) herätti huolestusta: Nähtiin ei vaan vaarana, vaan todennäköisenä kehityksenä sitä, että CFL:n suuntautumisen mukaisesti koko ohjelma johtaa virtuaalihankkeisiin ruohonjuurikohtaamisten kustannuksella.

- Kohtaamispaikkoja kuitenkin tarvitaan. Kasvokkain tutustuminen on hyvin tärkeää. Olemme menettämässä NFA:n lakkauttamisen ja kohtaamispaikan menettämisen myötä jotain sellaista, jota ei kannattaisi kevyesti hylätä, muistuttivat Björn Wallen ja Jukka Tainio.

Työväen Sivistysliiton pääsihteeri Jorma Turunen kantoi huolta Baltian mukanaolosta, sillä Baltia-yhteistyö oli keskeinen toimintamuoto Nordens Folkliga Akademissa ja nyt akatemia siis ajetaan alas. Myös CIMO:n Eija Wilén huomautti puhdaslinjaisten pohjoismaisten projektien olevan ajan hengen vastaisia.

- Se mikä CIMO:n kautta kulkevissa projektihankkeiden perusteella näyttäisi kiinnostavan, on sellainen yhteistyö, missä toisena tai jonakin osapuolena on Venäjä tai Baltia, hän totesi.

FOVU-ryhmä tekee esityksen muutoksista 12. marraskuuta ja Pohjoismaiden opetusministerit kokoontuvat keskustelemaan ja tekemään päätöksiä ennen vuoden loppua. Uudistuksen koulutuspoliittisina tavoitteina on julkilausuttu vahvistaa pohjoismaisen yhteistyön kautta kansallista kehitystä, vahvistaa inhimillisiä resursseja paikallistalouden ja paikalliskulttuurien perustana, laajentaa kompetensseja sekä vahvistaa elinikäisen oppimisen kautta koulutuksen ja elämänlaadun välistä yhteyttä.

Anneli Kajanto 